\title{
Modulus of Elasticity and Compressive Strength of Tuff Masonry: Results of a Wide Set of Flat-Jack Tests
}

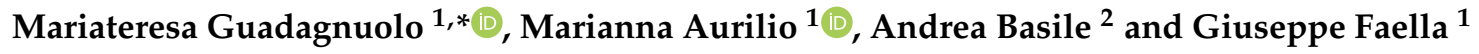 \\ 1 Department of Architecture and Industrial Design, Università degli Studi della Campania Luigi Vanvitelli, \\ Abbazia di San Lorenzo ad Septimum, Via S. Lorenzo, 81031 Aversa, Italy; \\ marianna.aurilio@unicampania.it (M.A.); giuseppe.faella@unicampania.it (G.F.) \\ 2 Tecnolab s.r.l., Via S. Maria del Pianto 80, 80143 Napoli, Italy; ingandreabasile@yahoo.com \\ * Correspondence: m.guadagnuolo@unicampania.it
}

Received: 20 February 2020; Accepted: 24 April 2020; Published: 28 April 2020

\begin{abstract}
The assessment of the modulus of elasticity and compressive strength of masonry is a fundamental step in the seismic analysis of existing structures. In this paper, the representativeness of the values provided by flat-jack tests for tuff masonry is investigated through the analysis of a very large and homogeneous number of tests ( 635 double flat-jack tests). Data relate to existing buildings belonging to different historical and/or construction periods, located throughout the Campania region (Italy) in areas with different peculiarities. Results are compared with the values provided by Italian Building Code, containing ranges of the elastic modulus and compressive strength for different types of masonry. The values of flat-jack tests are then compared with laboratory tests available in the literature. Finally, comparisons with code equations are performed. It is shown that equations correlating the masonry compressive strength with the modulus of elasticity provide values larger than the mean of experimental data, whereas the equations correlating the masonry compressive strength with the strength of components provide lower values, if block and mortar strengths are varied within a probable and wide range.
\end{abstract}

Keywords: tuff masonry; modulus of elasticity; compressive strength; flat-jack tests

\section{Introduction}

The assessment of the structural safety of existing masonry buildings and the evaluation of needed retrofitting interventions are fundamental issues in human health safeguarding and cultural heritage preservation. Within this framework, the knowledge or estimation of the masonry mechanical properties is an important step in the numerical evaluation of the seismic capacity of building structures. Among such properties, the modulus of elasticity and masonry compressive strength are the most important to be determined $[1,2]$.

The computation of the compressive strength is still a weak point of the entire analysis procedure, despite the considerable development in recent decades of techniques for their on-site assessment. Besides, there is also a partial lack of literature and standard values, because of the strong heterogeneity of masonry structures in terms of both materials and construction techniques [3-7]. This is relevant for natural stone masonries such as tuff and mortars with different strengths, often altered over time, which are widespread in the Campania region of Italy $[8,9]$.

Tuff is a rather soft, porous, and inhomogeneous material formed by the compaction and cementation of volcanic ash and dust. Several research works were concerned with the physic-mechanical parameters of tuff in the second half of the last century, but a thorough comparison of all the main data is lacking. Recent papers confirm the tuff's inhomogeneous behavior, although the deposit and outcrop are the 
same $[10,11]$. The physical and mechanical properties differ depending on the quarry location and depth of extraction.

The compressive strength, in particular, depends both on petrophysical features, the content of pumice, and the type of matrix: tuff is weak, characterized by low values of bulk density, medium-low compressive strength (with great variability between 1.2 and $9 \mathrm{MPa}$ ), and quite high porosity (the average being variable between 35\% and 60\%) [10-13].

Most masonry buildings in Southern Italy were built using hand-squared tuff blocks and pozzolanic mortar. The latter is a mix of ground lime and volcanic ash and has a medium-low compressive strength [14]. For many centuries, walls were made of solid tuff masonry, squared more or less roughly (Figure 1), while in the last two centuries, they were also made of two external wythes of tuff blocks, discontinuously tied, with the internal core filled with mortar and small stones. These masonry walls have different behavior when loaded in the plane and out of the plane [15-18], requiring, in the first case, a suitable estimate of the elastic moduli and strengths, necessary for the static and seismic analysis of the building behavior.

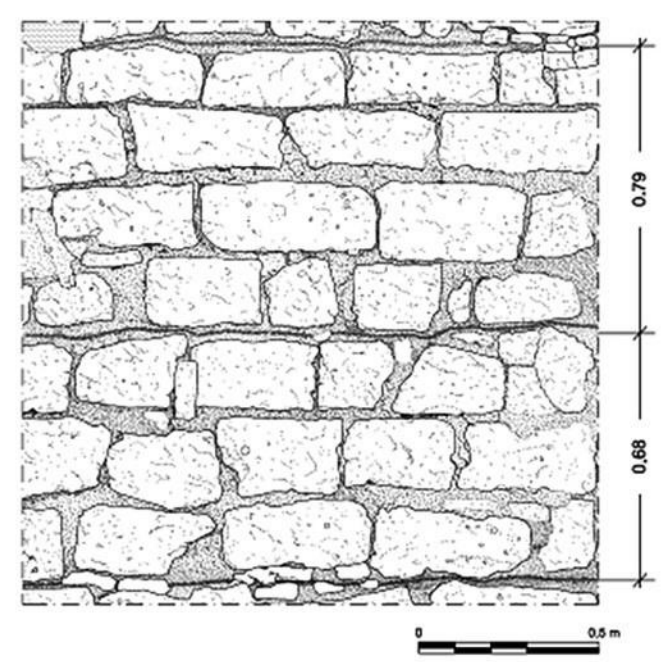

(a)

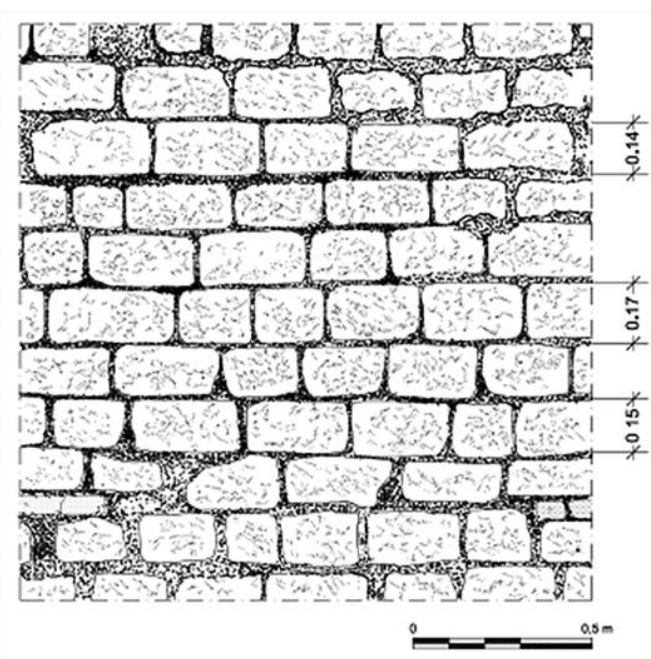

(b)

Figure 1. Tuff masonry in hand-squared blocks: (a) roughly squared; (b) smoothly squared [7].

The experimental determination of the mechanical properties (modulus of elasticity and compressive strength) of tuff masonries still presents some difficulties, and laboratory tests are seldom possible. Furthermore, the strong heterogeneity of tuff masonry also makes the use of numerical formulations complex, which combine the experimental strength of masonry components and table values.

Currently, numerical approaches and experimental techniques are feasible for assessing the above mechanical properties, differing in reliability, invasiveness, and costs. Some standard codes place great emphasis on the quality of these data, assuming that the design values depend on their reliability $[19,20]$. For this purpose, on-site tests continue to have a fundamental role, because of problems that characterize the laboratory tests of samples taken on-site or the non-representativeness of new laboratory samples [21-24].

Masonry codes usually provide empirical relations for estimating the modulus of elasticity using the compressive strength of masonry as the only parameter. Such an approach neglects the influence of the deformability of units and mortars and requires suitable linking coefficients. The equations for computing the masonry compressive strength as a function of blocks and mortar need both the knowledge of such strengths and the use of suitable combination coefficients. Hence, the numerical approaches are based on reliable existing data or values provided by standard codes. It is a complex approach because of the diversity of masonry types: this is due to the different periods of construction, 
the wide geographical location, and the great variety of materials used in the past, but also due to lacking valid databases [25].

Experimental determinations are more reliable. Today, they can be carried out by different techniques. Non-destructive techniques, based on on-site testing, are more achievable, as many masonry buildings belong to the cultural heritage $[26,27]$. However, their applicability and reliability depend very much on the construction technique of masonry walls. In recent years, several experimental procedures characterized by reliability and small damage in walls were developed (i.e., sonic and ultrasonic velocity test, surface-penetrating radar test, flat-jack test, infrared thermography test, fiberscope test, mortar rebound hammer testing) [7,28-36]. Some of them were also introduced into standard codes, but each one has features with advantages and inconveniencies $[20,37,38]$.

This paper deals with the on-site assessment (by 635 double flat-jack tests) of the elastic modulus and compressive strength of tuff masonry, widespread in the construction of monumental and ordinary buildings in Southern Italy. The values of the flat-jack tests are then compared with laboratory values provided by research [39-49]. Finally, comparisons with code equations correlating the masonry compressive strength with the modulus of elasticity or with the strength of the masonry components are performed.

\section{Materials and Methods}

\subsection{Elastic Modulus of Tuff Masonry}

The modulus of elasticity for the working-stress design purposes of existing masonry walls can be differently assessed, and building codes and research papers deal with different and known types of elastic moduli (Figure 2).

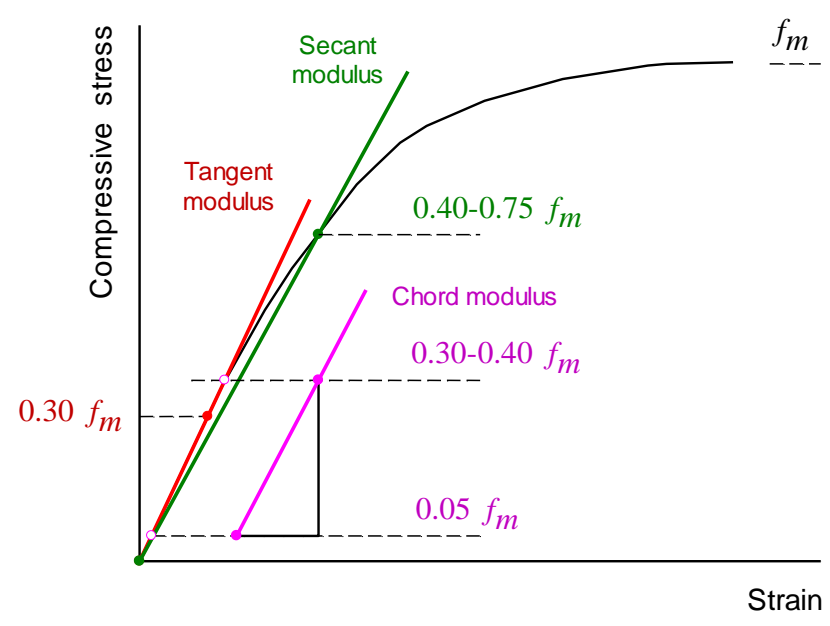

Figure 2. Types of elastic moduli.

The tangent modulus is the initial slope of the stress-strain curve below a prefixed stress value (usually less than $30 \%$ of the maximum compressive stress). However, starting data of experimental stress-strain relationships could be unreliable, because of the seating effect at the initial loading phase. The chord modulus is defined as the slope of a line intersecting the stress-strain curve at two prefixed points, frequently between $5 \%$ and $30-40 \%$ of the compressive strength. The secant modulus is the slope of a line that links the origin of the stress-strain relationship with a point intersecting the stress-strain curve to a prefixed stress value (often between $40 \%$ and $75 \%$ of the maximum compressive stress).

Standard codes address both experimental procedures and analytical approaches based on the use of relationships that bind the modulus of elasticity to the masonry strength or the masonry components [50,51].

Few research papers were aimed at experimentally computing the elastic modulus of tuff masonry components (blocks and mortar), and those available provided values with great variability. 
The experimental elastic modulus of tuff stones ranges between 800 and $3000 \mathrm{MPa}[42,47,52]$. Few experimental research works concerned the elastic modulus of pozzolanic mortars [14]. The chemical and mechanical properties of pure lime mortars were extensively studied [53-57], but the research works concerned new samples and may not be representative of the actual deformability of pozzolanic mortar layers in existing masonries. However, the elastic modulus of the pozzolanic mortar could be estimated to be about 800 times its compressive strength [47], consistent with the relationships usually proposed for weak mortars [58,59].

A slightly larger number of research works concerned the experimental assessment of the elastic modulus of tuff masonry. Most of them concerned tests on laboratory specimens since the extraction of masonry prisms of adequate size from walls is impossible (e.g., in the case of cultural heritage buildings), and the transportation of undisturbed samples is difficult [39-49].

Alternatively, the experimental assessment can be performed on-site. This is done by non-destructive or low-destructive tests, such as double flat-jack tests, which allow a direct determination of the elastic modulus, with the uncertainties described below.

Table 1 contains the main results of some laboratory tests performed on tuff masonry prismatic specimens. They showed a significant variability of the modulus of elasticity since it ranged between about 400 and $2200 \mathrm{MPa}$.

Table 1. Laboratory tests on tuff masonry specimens.

\begin{tabular}{|c|c|c|c|c|c|c|c|}
\hline \multirow{4}{*}{ Reference } & \multirow{4}{*}{$\begin{array}{c}\text { Tuff } \\
\text { Strength } \\
(\mathrm{MPa})\end{array}$} & \multirow{4}{*}{$\begin{array}{c}\text { Mortar } \\
\text { Strength }\end{array}$} & \multicolumn{5}{|c|}{ Masonry } \\
\hline & & & \multicolumn{3}{|c|}{ Specimen Size } & \multirow{3}{*}{$\begin{array}{c}\begin{array}{c}\text { Modulus of } \\
\text { Elasticity }\end{array} \\
\text { (MPa) }\end{array}$} & \multirow{3}{*}{$\begin{array}{c}\text { Compressive } \\
\text { Strength } \\
(\mathrm{MPa})\end{array}$} \\
\hline & & & $\mathbf{L}$ & H & $\mathbf{t}$ & & \\
\hline & & & $(\mathrm{cm})$ & $(\mathrm{cm})$ & $(\mathrm{cm})$ & & \\
\hline Bernardini et al. 1984 [39] & $4.98-6.46$ & $1.73-5.78$ & $82-104$ & $83-104$ & $12-25$ & $1650-2100$ & $3.05-4.26$ \\
\hline Faella et al. 1991 [40] & 3.50 & $2.0-3.0$ & 130 & 125 & 50 & 991-1110 & $1.23-1.53$ \\
\hline Prota et al. 2006 [41] & 2.00 & 5.00 & 103 & 103 & 25 & 680 & 2.30 \\
\hline Augenti, Romano 2007 [42] & 4.13 & 7.14 & 62 & 62 & 15 & 1980 & 4.31 \\
\hline Augenti, Parisi 2009 [43] & - & - & 61 & 65 & 15 & 2222 & 3.96 \\
\hline Calderoni et al. 2009 [44] & $3.49-4.30$ & $1.56-3.76$ & $100-133$ & $82-95$ & $42-67$ & $743-1252$ & $2.55-4.34$ \\
\hline Grande, Romano 2012 [45] & 4.13 & 7.14 & 61 & 60 & 15 & 781 & 1.97 \\
\hline Miccoli et al. 2015 [46] & 5.21 & 3.32 & 50 & 50 & 11.5 & $587-1071$ & $2.71-3.77$ \\
\hline Marcari et al. 2017 [47] & 8.00 & 6.60 & 100 & 100 & 25 & 1495-1869 & $2.67-2.70$ \\
\hline Alecci et al. 2019 [48] & 4.22 & 0.99 & 57 & 61 & 19 & 818 & $0.92-1.20$ \\
\hline Sandoli et al. 2019 [49] & 4.60 & 1.93 & $13.5-22$ & $30-40$ & $16.5-22$ & $385-393$ & $2.36-2.39$ \\
\hline
\end{tabular}

The scatter was mainly due to the differences in terms of the material properties, type of modulus, type of masonry (solid masonry or multi-wythe masonry), dimension of tuff blocks, thickness, and type of mortar (a predominance of cement and lime/cement mortars was found). Some papers also estimated the secant modulus, usually at $75 \%$ of the maximum stress. Such a value could be useful in the nonlinear seismic analysis of masonry buildings. Available research works showed that for tuff masonry, the ratio of the secant to the initial tangent modulus ranged between 0.33 and 0.74 [47].

Several researchers and building codes correlated the modulus of elasticity $E_{m}$ and masonry compressive strength $f_{m}$ according to the following equation, valid for generic new masonry:

$$
E_{m}=a \cdot f_{m}^{b}
$$

A great variation characterized the coefficients $a$ and $b$ in available research works since the coefficient $a$ ranged between 400 and 2500 and the coefficient $b$ between 0.5 and 1.0 [60-62]. This was also because different types of elastic moduli were computed (tangent modulus, chord modulus, secant modulus), as reported above.

Standard codes generally assume the coefficient $a$ to range between 550 and 1000 (the coefficient $b$ is assumed to equal 1). FEMA 306 [26] advises $E_{m}=550 f_{m}$, IBC 2003 [63] and MSJC 2002 [64] recommend $E_{m}$ as 700 times $f_{m}$, the Canadian masonry code advises $E_{m}$ as 850 times $f_{m}$ (with an upper 
limit of 20,000 MPa) [65], Eurocode 6 [37] and the Italian standard code (NTC 2018) advise a higher value $\left(E_{m}=1000 f_{m}\right)[19]$.

Several experimental research works showed that the ratio $E_{m} / f_{m}$ for tuff masonry ranged between 600 and 800 [40,47]. Some papers highlighted that the usual analytical equations provided values of the modulus of elasticity larger than the ones obtained by experimental tests since they did not consider, or inappropriately considered, the deformations of mortar bed joints [66]. Their deformation, under the average compressive masonry stress (about 33\% of masonry strength) could be up to 10 times greater than that of the standard laboratory samples [66].

Finally, some building codes provide tables containing ranges of the elastic modulus, depending on the masonry type [38]. Such an approach entails the obvious difficulty of contemplating all the many types of existing masonry, as well as the difficulty of grouping them correctly.

\subsection{Compressive Strength of Tuff Masonry}

The evaluation of the expected masonry strength involves some difficulties because of the great variability of masonry types and the many influencing parameters. Masonry compressive strength depends on that of blocks and mortar, the size of blocks, the thickness of the horizontal mortar layer, the evenness of block seats, the bonding of blocks, the filling of vertical joints, and the environmental parameters.

The state-of-the-art does not allow for a computation that considers all the above factors, and many empirical formulae predicting $f_{m}$ are available. They take into account some aforementioned parameters. Frequently, the strength of blocks and mortar is only considered. This could be adequate for brick masonries, and the pseudo-quantitative approaches are merely usable for existing buildings $[67,68]$.

Following an indirect approach, the masonry compressive strength can be computed as a function of the experimental strength of its components (blocks and mortar) [40,69-71]. This approach has the advantage of requiring moderately destructive sampling, but it is affected by the validity of the coefficients used in the equation, which cannot be the same if the materials and types of masonry vary.

All building codes $[38,72,73]$ provide equations to compute the masonry compressive strength $f_{m}$ as a function of block $\left(f_{b}\right)$ and mortar $\left(f_{j}\right)$ strength:

$$
f_{m}=\alpha \cdot f_{b}^{\beta} \cdot f_{j}^{\gamma}
$$

The coefficients $\alpha, \beta$, and $\gamma$ vary from code to code and are empirically determined based on experimental studies on recent materials. Therefore, for existing masonry with a lower strength of blocks or mortar, as the tuff ones, the error in estimating the masonry compressive strength is higher, and the above equation would require specific values of the above coefficients or additional correction factors [70].

In recent decades, some experimental research works showed that the compressive strength of tuff stones ranged between $2 \mathrm{MPa}$ and $6 \mathrm{MPa}[40-42,44,47,49,58,74,75]$. However, the strength of recently extracted tuff stones is often greater than that of blocks extracted from existing structures: the few tests on blocks taken from the demolition of structures in the Naples area showed strengths between 3.0 and 3.5 MPa [40,52].

The compressive strength of existing pozzolanic mortars is more complex to assess. The in situ measurement is difficult because of the thin thickness of beds. The extraction of samples from joints is problematic since the mortar is brittle and crumbles when removed from the original location. It is not possible to extract samples of a size suitable for reliable laboratory tests. Finally, the results of laboratory tests on new samples significantly depend on the mix and curing condition, which may alter their representativeness [76-78]. The few data available have been obtained by tests based on the measure of the energy required to drill a small cavity in the mortar layer [79-83]. Such tests repeatedly showed values between 1.20 and $2.50 \mathrm{MPa}$. These strength values were confirmed by some research works that concerned the characteristics of existing masonry [40,52]. 
As with the elastic modulus, several research works measured the compressive masonry strength on laboratory specimens. Given the impossibility of extracting samples from wall structures, laboratory tests were performed on newly built specimens, using materials with characteristics similar (but inevitably not equal) to the ones used when the structures were built. A large scatter characterized the results, as shown in Table 1 , since $f_{m}$ ranged between 0.92 and $4.34 \mathrm{MPa}$. This was due to differences in terms of material properties, specimen dimensions, masonry type, and experimental condition. Furthermore, in multi-wythe masonries, the compressive strength was frequently computed on the gross area of the specimen, neglecting the difference in the inner core and surrounding stone wythe. For the above reasons, alternative methods are developing: recently, the masonry's strength was identified by testing smaller samples (cores) extracted from the wall structure [84]. The procedure allows limiting damage to the masonry structure, but requires specific laboratory tests and interpretation of the results. The technique was verified for brick masonry, while for tuff masonry, it seemed less proper because of the differences in material properties and the larger size of tuff blocks compared to bricks. Within the above framework, double flat-jack tests have spread because of the advantage of testing masonry portions in situ, but they have the limitations listed below, mainly related to the compressive strength measurement [85].

When the in situ measurement of the material parameters is not feasible or reliable, some codes provide reference tables, compiled based on the experimental data available for the most common typologies $[38,86]$. As with the elastic modulus, these tables cannot be large enough to cover all possible masonries and must necessarily refer to generic types of masonry.

\section{Remarks on Double Flat-Jack Tests}

The flat-jack tests, originally developed for rock mechanics, were adapted to masonry structures at the end of the 1970s. In the following twenty years, they were particularly studied to ascertain their potential, also evaluated through comparative tests on-site and in the laboratory. Subsequent applications highlighted the degree of uncertainty that may characterize the interpretation of the results, and therefore the results themselves. The flat-jack test allows estimating the deformability properties of a solid-unit masonry portion and eventually the strength at the elastic limit state. Therefore, the test is not a rigorous technique for assessing the compressive strength.

A detailed explanation of this well-known testing can be found in [87]. The flat-jacks technique is also regulated by several ASTM and RILEM standards documents $[36,82,83,88]$. The installation is shown in Figure 3: two flat-jacks, inserted into parallel slots made in a solid-unit masonry wall, were pressurized, thus inducing compressive stress on the masonry between them. The slots must be parallel, vertically aligned, and separated by at least five courses of masonry in the case of a unit height equal to or less than $100 \mathrm{~mm}$ (brick-masonry) or three courses of masonry in the case of a unit height equal to or greater than $100 \mathrm{~mm}$ (stone-masonry) [82]. The load was applied to both flat-jacks equally in increments, and the distance between the gauging points was measured at each loading step. If the compressive strength were to be determined, the pressure should be increased until cracking was observed [89]. The pressure and displacement values were then converted into the stress-strain curve of the masonry [20].

The test was mainly used, and has been more reliable, to analyze brick masonry or squared blocks masonry, i.e., masonry of good workmanship, with quite regular mortar layers. The use for chaotic and very irregular masonry, on the other hand, raises some questions, and experiments have shown that it can lead to errors in the evaluation of both the modulus of elasticity and compressive strength [90]. Nevertheless, the flat-jack technique has been successfully used in numerous and different stone masonry structures [91-98], proving to be a valid alternative to measure the strain-stress behavior of masonry $[85,99,100]$.

An interesting comparison among the results of in situ tests on rubble masonry panels and double flat-jack tests was presented in [90]. The tests were carried out on a disused building and showed that 
the double flat-jack method allowed an adequately reliable prediction of the compressive strength, but was less capable of correctly evaluating the deformation modulus.

Some research works performed comparative analyses in the laboratory between load tests and flat-jack tests on similar masonry specimens $[85,101,102]$. They showed that in regular masonry, the error in the assessment of the elastic modulus is on average between $15 \%$ and $20 \%$ [103-105]. The error in the evaluation of the masonry strength is frequently estimated to be around $20 \%$. The ASTM code advises a variation coefficient of $15 \%$ in the evaluation of stress states and $24 \%$ in the evaluation of deformability parameters [88].

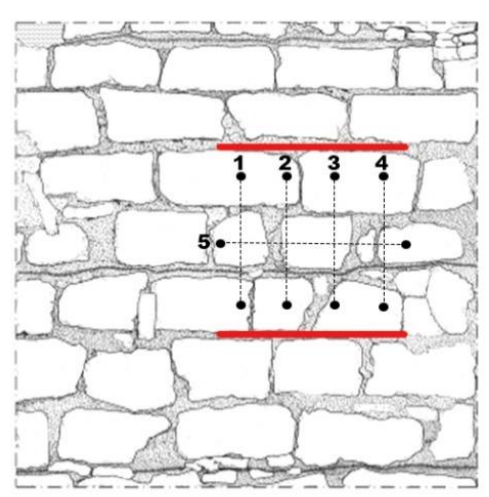

(a)

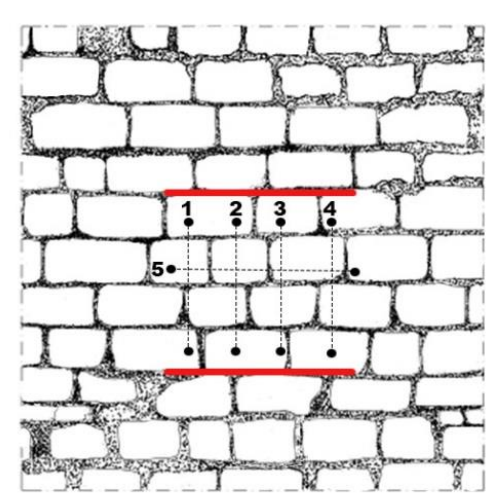

(b)

Figure 3. Double flat-jack setup: (a) roughly-squared blocks; (b) smoothly-squared blocks.

\section{Results and Discussion}

Numerous flat-jack tests were carried out by the authors in recent years to assess the mechanical properties of the tuff masonry of existing buildings of the Campania region in Italy. All double flat-jack tests were performed according to the RILEM provision [82], always using the same test setup (Figure 3). Semi-circular jacks $3.5 \mathrm{~mm}$ thick, $257 \mathrm{~mm}$ deep, and $347 \mathrm{~mm}$ in diameter were usually used. The preliminary calibration tests systematically led to evaluating the flat-jack coefficient and the ratio of the flat-jack area to the average slot area, necessary to correct the experimental data. The pressure was increased based on the results obtained from the previous test with a single flat-jack, with values on average of about 0.5 bar for each step; the displacement in eight points was registered in each test (Figure 3). The mean stress-strain curve was then computed using these values (Figure 4).

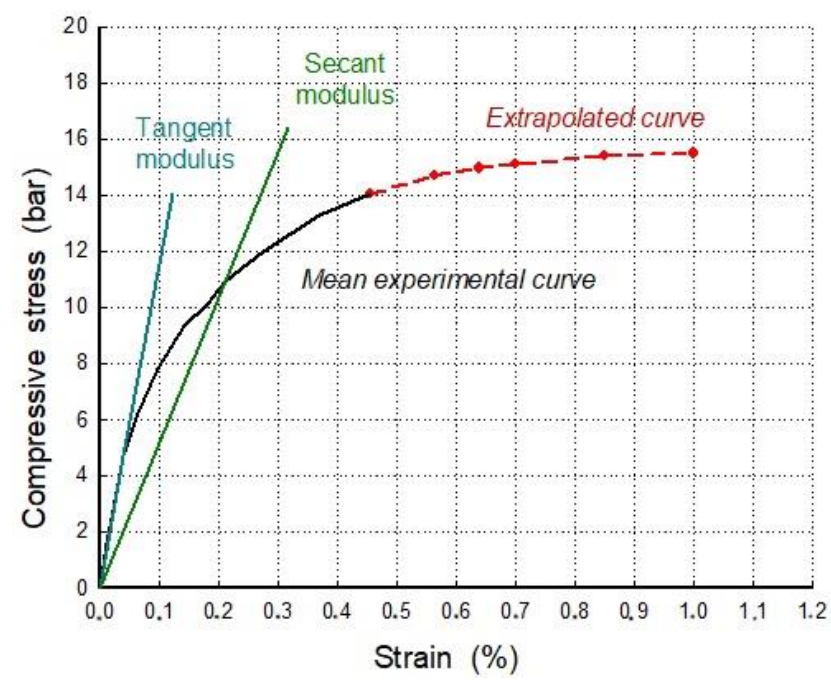

Figure 4. Experimental stress-strain curve. 
Figure 4 shows, as an example, the experimental curve obtained in a test, together with the curve extrapolated for assessing the masonry strength and the straight lines used for calculating the tangent and secant modulus of elasticity, respectively, computed at $30 \%$ and $75 \%$ of the estimated strength.

The database processed in this paper related to a large sample of tuff masonry buildings, belonging to different historical and/or construction periods. They regarded 635 double flat-jack tests: 532 tests related to course masonry made of smoothly-squared blocks, and 103 tests related to course masonry made of roughly-squared blocks. It must be stated that in both cases, the blocks were squared by hand and therefore not comparable with today's industrial production of tuff blocks (well-squared blocks). Each test included both the evaluation of the elastic modulus and the assessment of the compressive strength.

As mentioned above, the elastic modulus and compressive strengths of tuff masonry depend on many factors, and one of the main issues concerns the difference between the failure mechanism of course masonry made of regular (squared) units and that of masonry made of irregular units. It is well known that the main failure mechanism of squared block masonry under uniaxial compression is controlled by the horizontal tensile stresses acting on the blocks, because of the larger horizontal displacements of the mortar (because of the Poisson deformation) [106]. Therefore, the tensile strength of masonry units contributes when loads approach the maximum strength of masonry, after crack development and in the case of low quality mortar $[107,108]$. The favorable triaxial compressive stress state of mortar in brickwork, due to the higher strength and modulus of elasticity of bricks than the ones of weak mortar joints, applies for well-squared coursed masonry, but not for irregular sharp-edged stone masonry. In the latter case, a more complex stress state develops on blocks, mainly on the sharp edges, and affects the compressive behavior. In fact, in the case of irregular stones, a rubble block could be seated on its supporting stone on one point only, generating several transversal splitting stresses.

\subsection{Modulus of Elasticity}

Figure 5 shows the frequency distribution of the modulus of elasticity and compressive strength computed for masonries made of smoothly- and roughly-squared blocks. The elastic modulus $E_{m}$ was determined as the chord modulus equal to the mean of the values computed between about $5 \%$ and $30 \%$ of the estimated compressive strength. Table 2 shows the mean value, the standard deviation, and the coefficient of variation as the quality of block squaring varied.

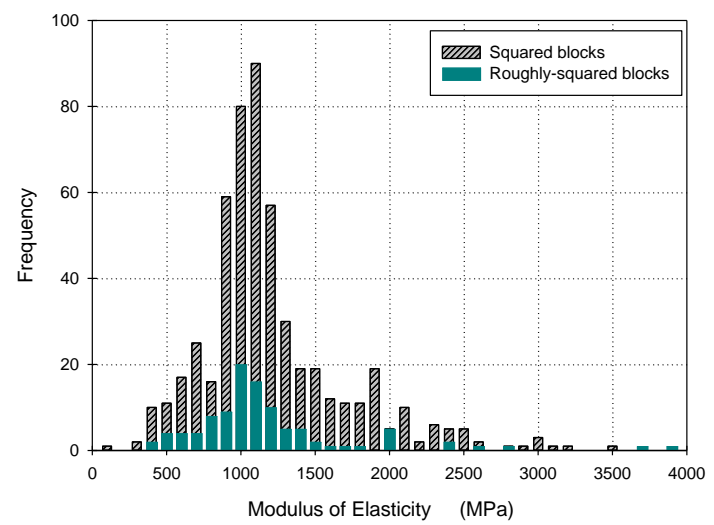

(a)

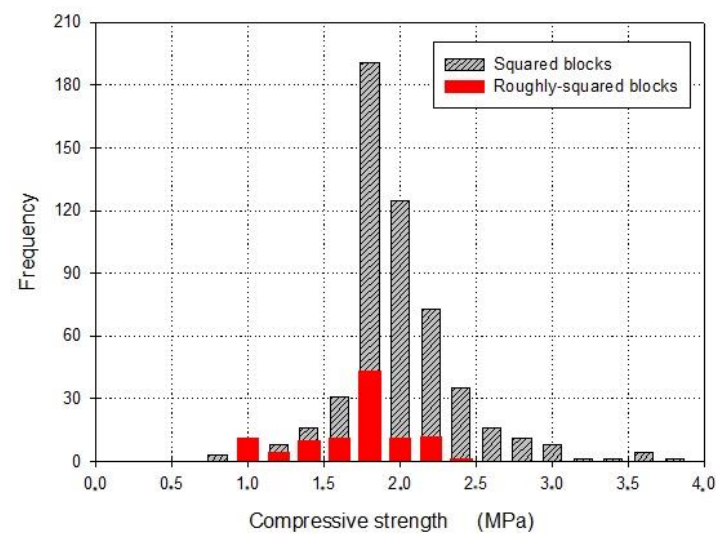

(b)

Figure 5. Frequency distribution of (a) the modulus of elasticity and (b) compressive strength of smoothly- and roughly-squared block masonry. 
Table 2. Mean values of flat-jack results on tuff masonry.

\begin{tabular}{ccccc}
\hline & \multicolumn{2}{c}{ Elastic Modulus } & \multicolumn{2}{c}{ Compressive Strength } \\
\hline Blocks & Squared & Roughly Squared & Squared & Roughly Squared \\
\hline Mean value (MPa) & 1209 & 1197 & 2.01 & 1.71 \\
Standard deviation (MPa) & 489 & 672 & 0.42 & 0.36 \\
Coefficient of variation (\%) & 40.45 & 56.16 & 20.92 & 21.06 \\
\hline
\end{tabular}

The values of Figure 5 and Table 2 confirmed a similarity in the values of the mechanical parameters, highlighting a modest influence of the squaring quality of blocks. Quality, thickness, and state of deterioration of mortar beds largely influence the behavior under compression of both the examined masonry types and in well-squared masonry, because of the greater amount of weak mortar around stones $[109,110]$. In addition, although carefully made, the masonry cuts to arrange the flat-jacks did not always involve only mortar layers, but sometimes also portions of blocks, especially in the roughly-squared block masonry.

This brought the mechanical properties of the two types of analyzed masonry closer together. For these reasons, in the following, the experimental data were processed as data from a single sample, eliminating the difference between smoothly- and roughly-squared blocks.

Figure 6 shows the frequency distribution of the modulus of elasticity $E_{m}$ computed for the entire database of double flat-jack tests (635 tests). The mean value of $E_{m}$ was equal to $1206 \mathrm{MPa}$, while the distribution was characterized by a standard deviation equal to $522 \mathrm{MPa}$ and by a coefficient of variation equal to $43.29 \%$.

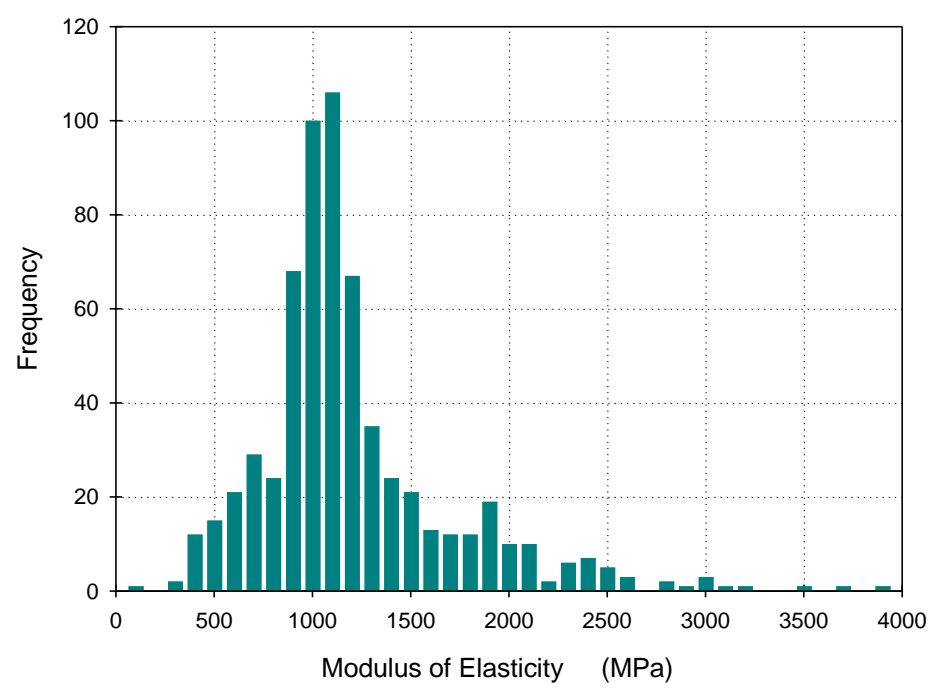

Figure 6. Frequency distribution of the modulus of elasticity for the entire experimental dataset.

A plausible range containing the mean value was provided by the confidence interval. For the above distribution, the standard error of the mean was equal to $20.73 \mathrm{MPa}$, and the confidence interval identified the range 1166-1248 MPa, computed for a confidence level of $95 \%$ and assuming Student's $t$-distribution (characterized by greater dispersion than the normal standard).

The mean value of $E_{m}$ was included in the wide range of values provided by laboratory tests on tuff masonry specimens, as reported above. Mostly, it was quite consistent with the values provided by the Italian Building Code for irregular tuff masonry (900-1260 MPa), but lower than those suggested for regular tuff masonry (1200-1620 MPa) [38]. The numerous analyzed flat-jack tests provided an intermediate value between the two code ranges and a mean value lower than the one proposed for regular masonry. 
Further data of interest were the ratio between the secant modulus $E_{s e c}$ and the modulus $E_{m}$. The secant modulus was computed at stress equal to about $75 \%$ of the compressive strength. Figure 7 shows the frequency distribution of the $E_{s e c} / E_{m}$ ratio, which had a mean value of 0.58 . This was consistent with the values already determined by other authors through compression tests on panels in the laboratory, as reported above. The standard deviation of the distribution was equal to 0.10 , while the coefficient of variation was $17.63 \%$.

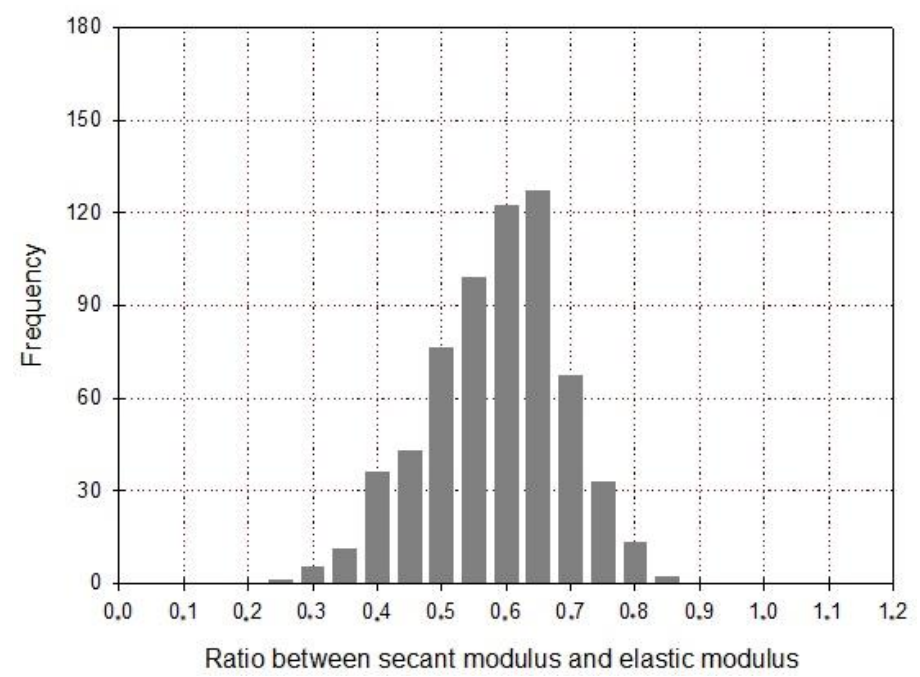

Figure 7. Frequency distribution of the ratio between the secant modulus and elastic modulus.

\subsection{Compressive Strength}

Figure 8 shows the frequency distribution of the compressive strength $f_{m}$ computed for the entire set of 635 flat-jack tests. The mean value was equal to $1.96 \mathrm{MPa}$, while the standard deviation and the coefficient of variation were equal to $0.42 \mathrm{MPa}$ and $21.71 \%$, respectively. The standard error of the mean was equal to $0.0169 \mathrm{MPa}$, and the confidence interval identified the range of 1.930-1.996 $\mathrm{MPa}$ (computed for a confidence level of $95 \%$ and assuming Student's $t$-distribution).

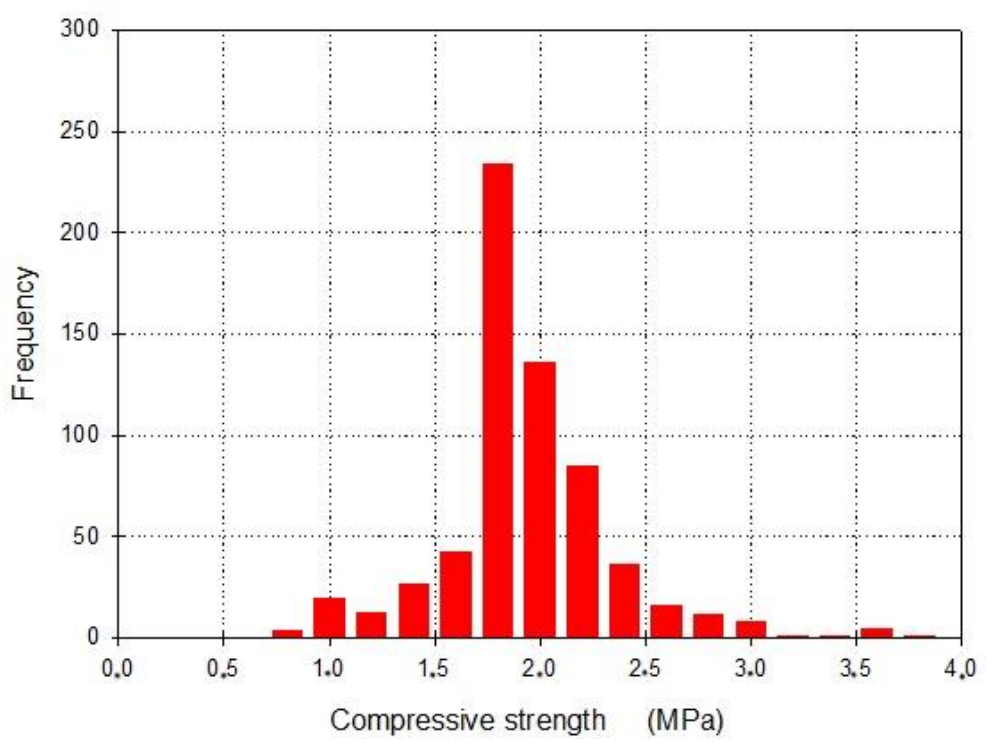

Figure 8. Frequency distribution of compressive strength for the entire experimental dataset.

The mean compressive strength was less than the ones provided by laboratory tests (Table 1), since the specimens often had different geometrical and strength characteristics than actual masonry. 
The specimens were mostly made by recent and well-squared tuff blocks, mortars with compressive strength generally greater than that of existing structures, and more accurate masonry arrangement. The mortar strength was the element that most influenced the masonry strength: actual mortars were pozzolanic and degraded in strength, while laboratory mortars often had a cement matrix that inevitably led to a higher strength.

The masonry compressive strength provided by flat-jack tests was consistent with those proposed by the Italian Building Code for irregular tuff masonry (the range of 1.4-2.2 MPa is advised), but lower than those provided for regular masonry (2.0-3.2 MPa) [38]. This implied that all tuff masonries in hand-squared blocks (regardless of quality) should be assimilated to irregular masonry.

As stated above, building codes provide an equation for calculating the masonry compressive strength as a function of block and mortar strength (Equation (2)). Eurocode 6 [37] and NTC 2018 [19] advise $\alpha=0.45, \beta=0.70$, and $\gamma=0.30$ for the coefficients of Equation (2).

Figure 9 contains all the compressive strengths provided by the double flat-jack tests and some thresholds determined by varying the strength of tuff blocks and pozzolanic mortar within a probable and wide range. The compressive strength of tuff blocks was varied between 2.5 and $4 \mathrm{MPa}$, while that of pozzolanic mortar between 1.0 and $5.0 \mathrm{MPa}$; the latter value was also quite higher than the strengths usually measured in situ. Nevertheless, Figure 9 shows that even assuming the highest values for $f_{b}$ and $f_{j}$, the masonry strength $f_{m}$ computed by Equation (2), as provided by Eurocode 6 [37] and NTC 2018 [19], did not envelop all the experimental data.

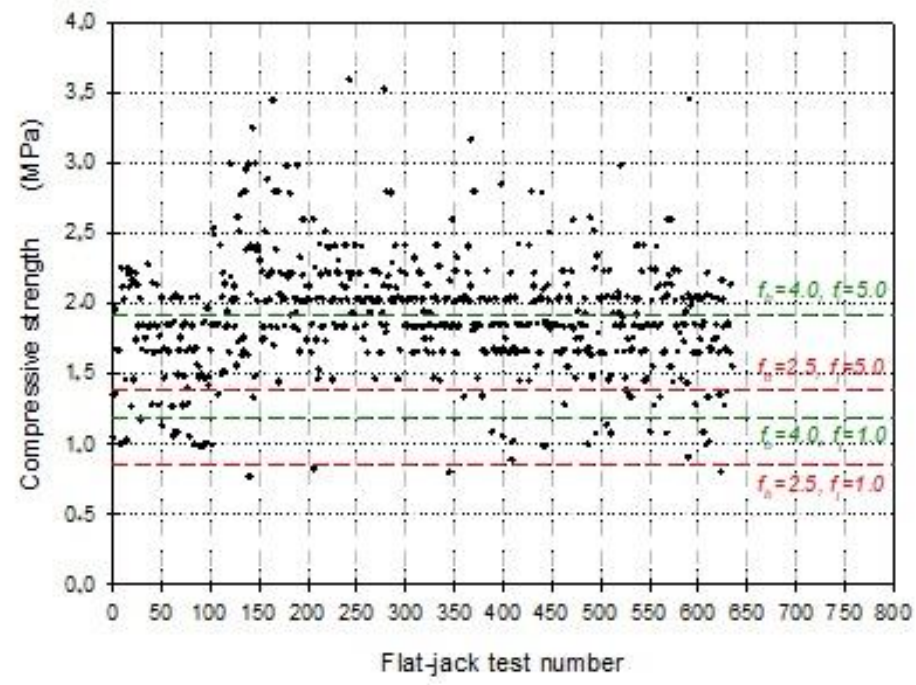

Figure 9. Masonry compressive strength as a function of block and mortar strength (Equation (2)).

\subsection{Modulus of Elasticity vs. Compressive Strength}

Figure 10 shows the frequency distribution of the ratio between $E_{m}$ and $f_{m}$ for all the flat-jack tests. The ratio was quite constant, with the mean value equal to 632 . This value was consistent, albeit smaller, with the value determined in [40,47], but was lower than the value frequently advised in building codes (assumed equal to $1000[19,37]$ ).

The Italian Building Code [38] is one of the few codes that provides tables containing values for both elastic modulus and compressive strength for existing buildings. For irregular tuff masonry, the ratio between the table values of $E_{m}$ and $f_{m}$ ranged between 573 and 643, while for regular tuff masonry, it was between 506 and 600. The average value provided by the flat-jack tests was therefore consistent with those of the Italian code [38]. Finally, if it were assumed that flat-jacks provided an underestimation of compressive strength [85], the ratio between $E_{m}$ and $f_{m}$ should take lower values than those determined here. 


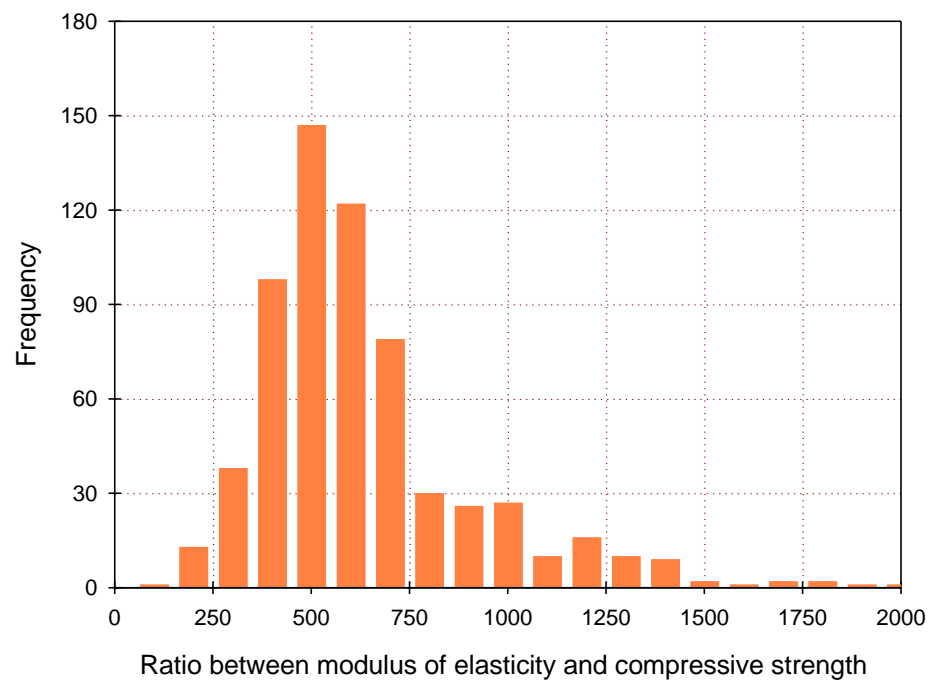

Figure 10. Frequency distribution of the ratio between the modulus of elasticity and compressive strength.

All values of elastic modulus and compressive strength are plotted together in Figure 11. The same figure also shows the red line that identifies Equation (1) as proposed by Eurocode 6 and the Italian code $[37,38]$, as well as two lines corresponding to Equation (1) where the coefficient a was assumed equal to 800 (blue line) and 600 (green line) and the coefficient $b$ equal to one. Obviously, considering the above, Figure 11 shows how the equation provided by the above codes did not well fit the experimental values of existing tuff masonry.

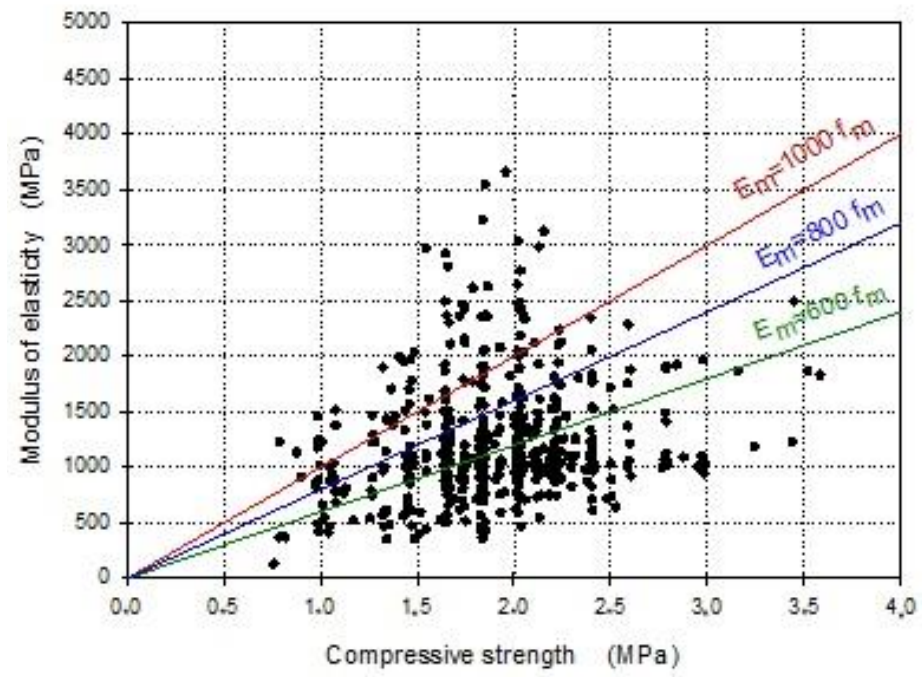

Figure 11. Modulus of elasticity vs. compressive strength.

\section{Conclusions}

The evaluation of the modulus of elasticity and compressive strength of masonry is a fundamental step in the seismic analysis of existing structures. These parameters can be determined through different approaches and procedures: among these, the methodology based on double flat-jack tests is particularly widespread, due to its simplicity and possibility to operate in situ, despite the uncertainties and approximations inherent in the method, synthetically discussed also in this paper.

Most existing masonry buildings in the Campania region (Italy) are tuff masonry with pozzolanic mortars and belong to different historical and construction periods. The results of numerous flat-jack tests performed by the authors, presented and discussed in this paper, could be useful for a suitable 
quantification of the elastic modulus and compressive strength of these masonries, allowing a more reliable assessment of the building seismic capacity.

Data of 635 double flat-jack tests performed on existing tuff masonry buildings were processed in the paper. Each test concerned both the evaluation of the modulus of elasticity and compressive strength of tuff masonry. Most of them related to tuff masonry in fairly smoothly-squared blocks while a smaller number related to roughly-squared blocks. In this respect, it should be considered that most blocks were squared by hand, and therefore, they were different from new and well-squared industrial tuff blocks.

The results of processed flat-jack tests confirmed a considerable independence from the hand-squaring quality (more or less rough) for both the modulus of elasticity and compressive strength. In fact, in masonries made of well-squared blocks, the flat-jacks could be positioned in the mortar beds, allowing a more "regular" test. In the case of masonry made of more or less roughly-squared blocks, the flat-jacks could, instead, be positioned either in correspondence with the mortar bed (which changes thickness because of the masonry irregularity) or in correspondence with cuts partially made on the blocks. In the presence of soft stones such as tuff, moreover, the quality of the mortar had a greater impact on both the elastic modulus and the compressive strength.

The flat-jack tests provided an average modulus of elasticity equal to $1206 \mathrm{MPa}$ and a probable range between 1166 and $1248 \mathrm{MPa}$. These values were quite consistent with those proposed by the Italian Building Code for irregular tuff masonry, but lower than those suggested for regular tuff masonry's mean compressive strength of $1.96 \mathrm{MPa}$, and a probable range of 1.93-2.0 MPa was computed by all the flat-jack tests. These values fully matched those proposed by the Italian code for irregular tuff masonry, but were lower than those advised for regular masonry. This should imply that tuff masonries made of hand-squared blocks (regardless of quality) should be assimilated to irregular tuff masonry.

The values provided by the flat-jack tests were compared with those of some laboratory results available in the literature. The comparison was more complex because many laboratory tests were related to specimens made of well-squared blocks and cement mortars. This meant that the flat-jack tests led to values on average lower than those provided by the laboratories, as shown in the paper.

Finally, all data were compared with the ones provided by code equations correlating the masonry compressive strength with the modulus of elasticity or with the strength of masonry components. In the first case, it was found that the equation advised by many codes (including Eurocode 6 and the Italian code), generally valid for new buildings, used a ratio between the elastic modulus and compressive strength greater than the mean value determined by processing the flat-jack data. The latter was very close to the ratio that could be determined using the tabular values proposed by the Italian code. The equation provided by the above two codes for computing the masonry strength as a function of block and mortar strength led to compressive strength somewhat lower than that determined by flat-jacks, if block and mortar strength was varied within a probable and wide range.

Author Contributions: Conceptualization, M.G., A.B., and G.F.; methodology, M.G. and G.F.; software, G.F.; validation, M.G.; formal analysis, M.A. and M.G.; resources, M.G. and A.B.; data curation, M.G.; writing, original draft preparation, M.G.; writing, review and editing, M.G. and G.F. All authors have read and agreed to the published version of the manuscript.

Funding: This research received no external funding.

Acknowledgments: The contribute of the Ministry of Education, University and Research and, in particular, the Basic Research Activities Fund (FFABR) is gratefully acknowledged.

Conflicts of Interest: The authors declare no conflict of interest. The funders had no role in the design of the study; in the collection, analyses, or interpretation of data; in the writing of the manuscript; nor in the decision to publish the results. 


\section{References}

1. Monaco, M.; Bergamasco, I.; Betti, M. A no-tension analysis for a brick masonry vault with lunette. J. Mech. Mat. Struct. 2018, 13, 703-714. [CrossRef]

2. Faella, G.; Giordano, A.; Guadagnuolo, M. Unsymmetric-plan masonry buildings: Pushover vs nonlinear dynamic analysis. In Proceedings of the 9th US National and 10th Canadian Conference on Earthquake Engineering, Toronto, ON, Canada, 25-29 July 2010.

3. Corradi, M.; Borri, A.; Vignoli, A. Experimental study on determination of strength of Masonry Walls. Constr. Build. Mater. 2003, 17, 325-337. [CrossRef]

4. Fonti, R.; Barthel, R.; Formisano, A.; Borri, A.; Candela, M. Rubble masonry response under cyclic actions: The experience of L'Aquila city (Italy). In Proceedings of the 11th International Conference of Computational Methods in Sciences and Engineering, ICCMSE, Athens, Greece, 20-23 March 2015; Volume 1702, p. 160003.

5. Marghella, G.; Marzo, A.; Carpani, B.; Indirli, M.; Formisano, A. Comparison between in situ experimental data and Italian code standard values. In Brick and Block Masonry: Trends, Innovations and Challenges, Proceedings of the 16th International Brick and Block Masonry Conference, Padova, Italy, 26-30 June 2016; IBMAC: Padova, Italy, 2016; pp. 707-1714.

6. Simões, A.; Gago, A.; Lopes, M.; Bento, R. Characterization of old masonry walls: Flat jack method. In Proceedings of the 15th World Conference on Earthquake Engineering, Lisbon, Portugal, 24-28 September 2012.

7. Faella, G.; Frunzio, G.; Guadagnuolo, M.; Donadio, A.; Ferri, L. The church of the nativity in Bethlehem: Non-destructive tests for the structural knowledge. J. Cult. Herit. 2012, 1296-2074. [CrossRef]

8. Fiengo, G.; Guerriero, L. Atlante Delle Tecniche Costruttive Tradizionali Napoli terra di lavoro (XVI-XIX); Arte Tipografica: Napoli, Italy, 2008; ISBN 8887375402.

9. Guadagnuolo, M.; Nuzzo, M.; Faella, G. The corpus domini bell tower: Conservation and safety. In Proceedings of the XIV International Conference on Building Pathology and Constructions Repair-CINPAR 2018, Florence, Italy, 20-22 June 2018. [CrossRef]

10. Colella, A.; Di Benedetto, C.; Calcaterra, D.; Cappelletti, P.; D’Amore, M.; Di Martire, D.; Graziano, S.F.; Papa, L.; de Gennaro, M.; Langella, A. The neapolitan yellow tuff: An outstanding example of heterogeneity. Constr. Build. Mater. 2017, 136, 361-373. [CrossRef]

11. De Vivo, B. Volcanism in the Campania Plain: Vesuvius, Campi Flegrei and Ignimbrites; Elsevier: Amsterdam, The Netherlands, 2006; Volume 9.

12. Kržan, M.; Gostic, S.; Cattari, S.; Bosiljkov, V. Acquiring reference parameters of masonry for the structural performance analysis of historical buildings. Bull. Earthq. Eng. 2015, 13, 203-236. [CrossRef]

13. Jackson, M.; Marra, F. Roman stone masonry: Volcanic foundation of the ancient city. J. Arch. Inst. Am. 2006, 110, 403-436. [CrossRef]

14. Guadagnuolo, M.; Monaco, M.; Frunzio, G.; Tafuro, A. Pozzolanic mortars for restoration of sacred tuff masonry structures. In Proceedings of the Utopian and Sacred Architecture, Aversa, Italy, 11-13 June 2019.

15. Guadagnuolo, M.; Donadio, A.; Faella, G. Out-of-plane failure mechanism of masonry buildings corners. In Proceedings of the 8th International Conference on Structural Analysis of Historical Constructions (SAHC), Wroclaw, Poland, 15-17 October 2012; ISSN 0860-2395. ISBN 9788371252167.

16. Monaco, M.; Guadagnuolo, M. Out of plane behaviour of unreinforced masonry walls. In Proceedings of the Prohitech-Protection of Historical Buildings-First International Conference, Rome, Italy, 21-24 June 2009; ISBN 9780415558037.

17. Guadagnuolo, M.; Faella, G. Simplified design of masonry ring-beams reinforced by flax fibers for existing buildings retrofitting. Buildings 2020, 10, 12. [CrossRef]

18. Guadagnuolo, M.; Aurilio, M.; Tafuro, A.; Faella, G. Analysis of local mechanisms through floor spectra for the preservation of historical masonries. A case study. In Proceedings of the 7th International Conference on Computational Methods in Structural Dynamics and Earthquake Engineering, Crete, Greece, 24-26 June 2019.

19. M.I.T. Aggiornamento delle Norme Tecniche per le Costruzioni; Ministero delle Infrastrutture e dei Trasporti: Rome, Italy, 2018. Available online: https://www.gazzettaufficiale.it/eli/gu/2018/02/20/42/so/8/sg/pdf (accessed on 1 April 2020).

20. FEMA, Federal Emergency Management Agency, FEMA 306. Evaluation of Earthquake Damaged Concrete and Masonry Wall Buildings, Basic Procedures Manual; Applied Technology Council: Redwood City, CA, USA, 1999; ATC-43. 
21. Borri, A.; Castori, G.; Corradi, M.; Speranzini, E. Shear behaviour of unreinforced and reinforced masonry panels subjected to insitu diagonal compression tests. Constr. Build. Mater. 2011, 25, 4403-4414. [CrossRef]

22. Brignola, A.; Frumento, S.; Lagomarsino, S.; Podestà, S. Identification of shear parameters of masonry panels through the in situ diagonal compression test. Int. J. Archit. Herit. 2009, 3, 52-73. [CrossRef]

23. Chiostrini, S.; Galano, L.; Vignoli, A. In Situ Shear and Compression Tests in Ancient Stone Masonry Walls of Tuscany, Italy. J. Test. Eval. 2003, 31, 289-303.

24. Calderini, C.; Cattari, S.; Lagomarsino, S. The use of the diagonal compression test to identify the shear mechanical parameters of masonry. Constr. Build. Mater. 2010, 24, 677-685. [CrossRef]

25. Buonocore, G.; Gesualdo, A.; Monaco, M.; Savino, M.T. Improvement of seismic performance of unreinforced masonry buildings using steel frames. In Civil-Comp Proceedings: 106, 2014; Topping, B.H.V., Iványi, P., Eds.; Civil Comp Press: Kippen, Stirlingshire, UK; ISBN 978-1-905088-61-4. [CrossRef]

26. Guadagnuolo, M.; Faella, G.; Donadio, A.; Ferri, L. Integrated evaluation of the Church of S.Nicola di Mira: Conservation versus safety. NDT E E Int. 2014. [CrossRef]

27. Frunzio, G.; Di Gennaro, L.; Guadagnuolo, M. Palazzo Ducale in Parete: Remarks on code provisions. Int. J. Mas. Resear. Inn. 2019, 4, 159-173. [CrossRef]

28. Binda, L.; Saisi, A. Application of NDTs to the diagnosis of historic structures. In Proceedings of the Non-Destructive Testing in Civil Engineering, Nantes, France, 30 June-3 July 2009.

29. Binda, L.; Saisi, A.; Tiraboschi, C. Application of sonic tests to the diagnosis of damage and repaired structures. NDT $\mathcal{E}$ E Int. 2001, 34, 123-138. [CrossRef]

30. Binda, L.; Saisi, A.; Zanzi, L. Sonic tomography and flat jack tests as complementary investigation procedures for the stone pillars of the temple of S.Nicolo' l'Arena (Italy). NDT \& E Int. 2003, 36, 215-227. [CrossRef]

31. Lindqvist, J.E.; Maurenbrecher, P. Testing of hardened mortars, a process of questioning and interpreting. A publication from RILEM TC 203-RHM Repair mortars for historic masonry. Mat. Struct. 2009, 47, 853-865.

32. CEN European Committee for Standardization. Non-destructive testing-Ultrasonic examination-Part 1: General Principles, Part 2: Sensitivity and Range Setting, Part 3: Transmission Technique, Part 4: Examination for Discontinuities Perpendicular to the Surface, Part 5: Characterization and Sizing of Discontinuities; CEN: Belgium, Brussels, 2000.

33. ASTM. Standard Guide for Using the Surface Ground Penetrating Radar Method for Subsurface Investigation; ASTM International: West Conshohocken, PA, USA, 2011. Available online: https://www.astm.org/DATABASE. CART/HISTORICAL/D6432-11.htm (accessed on 1 April 2020).

34. BS EN 13187:1999, Thermal Performance of Buildings - Qualitative Detection of Thermal Properties in Building Envelopes - Infrared Method; Infrared Thermography Handbook; Volume 1: Principles and practice, Norman Walker; Volume 2: Applications, A.N. Nowicki; BSI: London, UK, 2005.

35. Miranda, L.; Guedes, J.; Rio, J.; Costa, A. Stone masonry characterization through sonic tests. In Proceedings of the VI Congreso International Sobre Patologia y Recuperacion de Estructuras, Cordoba, Argentina, 2-4 June 2010.

36. ASTM C1196-09. Standard Test Method for In-Situ Compressive Stress Within Solid Unit Masonry Estimated Using Flat-Jack Measurements; ASTM International: West Conshohocken, PA, USA, 2009. Available online: https://www.astm.org/DATABASE.CART/HISTORICAL/C1196-09.htm (accessed on 1 April 2020).

37. CEN, European Committee for Standardization. Eurocode 6, EN 1996-1-1: Design of Masonry Structures-Part 1-1: General Rules for Reinforced and Unreinforced Masonry Structures; CEN: Belgium, Brussels, 2005.

38. M.I.T. Istruzioni per l'applicazione dell'aggiornamento delle Norme Tecniche per le Costruzioni di, Gazzetta Ufficiale: Rome, Italy. 2019. Available online: https:/www.gazzettaufficiale.it/eli/gu/2019/02/11/35/so/5/sg/ pdf (accessed on 1 April 2020).

39. Bernardini, A.; Mattone, R.; Modena, C.; Pasero, G.; Pavano, M.M.; Pistone, G.; Roccati, R.; Zaupa, F. Determinazione delle capacità portanti per carichi verticali e laterali di pannelli murari in tufo. Atti II Congr. Naz, 1984, pp. 345-360. Available online: http://www.reluis.it/mada/foto/026.pdf (accessed on 1 April 2020).

40. Faella, G.; Manfredi, G.; Realfonzo, R. Experimental evaluation of mechanical properties of old tuff masonry panels subjected to axial loadings. In Proceedings of the 9th International Brick/Block Masonry Conference, Berlin, Germany, 13-16 October 1991.

41. Prota, A.; Marcari, G.; Fabbrocino, G.; Manfredi, G.; Aldea, C. Experimental in-plane behaviour of tuff masonry strengthened with cementitious matrix-Grid composites. ASCE J. Comp. Constr. 2006, 10, 223-233. [CrossRef]

42. Augenti, N.; Romano, A. Preliminary experimental results for advanced modelling of tuff masonry structures. In Proceedings of the Structural Analysis of Historical Constructions, SAHC08, Bath, UK, 2-4 July 2008. 
43. Augenti, N.; Parisi, F. Mechanical characterization of tuff masonry. In Proceedings of the 1st International Conference on Protection of Historical Buildings, Rome, Italy, 21 June 2009; pp. 1579-1584.

44. Calderoni, B.; Cordasco, E.A.; Guerriero, L.; Lenza, P.; Manfredi, G. Mechanical behaviour of postmedieval tuff masonry in the Naples area. Mason. Int. 2009, 21, 85-96.

45. Grande, E.; Romano, A. Experimental investigation and numerical analysis of tuff-brick listed masonry panels. Mat. Struct. 2012, 46, 63-75. [CrossRef]

46. Miccoli, L.; Garofano, A.; Fontana, P.; Müller, U. Experimental testing and finite element modelling of earth block masonry. Eng. Struct. 2015, 104, 80-94. [CrossRef]

47. Marcari, G.; Basili, M.; Vestroni, F. Experimental investigation of tuff masonry panels reinforced with surface bonded basalt textile-reinforced mortar. Compos. Part B Eng. 2017, 108, 131-142. [CrossRef]

48. Alecci, V.; Stipo, G.; La Brusco, A.; De Stefano, M.; Rovero, L. Estimating elastic modulus of tuff and brick masonry: A comparison between on-site and laboratory tests. Constr. Build. Mater. 2019, 204, 828-838. [CrossRef]

49. Sandoli, A.; Ferracuti, B.; Calderoni, B. FRP-confined tuff masonry columns: Regular and irregular stone arrangement. Compos. Part B Eng. 2019, 162, 621-630. [CrossRef]

50. Gesualdo, A.; Calderoni, B.; Sandoli, A.; Monaco, M. Minimum energy approach for the in-plane shear resistance of masonry panels. Ing. Sismica 2019, 36, 42-53.

51. Gesualdo, A.; Calderoni, B.; Iannuzzo, A.; Fortunato, A.; Monaco, M. Minimum energy strategies for the in-plane behaviour of masonry. Frat. Ed Int. Strut. 2020, 14, 376-385. [CrossRef]

52. Ceroni, F.; Pecce, M.; Manfredi, G.; Marcari, G.; Voto, S. Analisi e caratterizzazione meccanica di murature di tufo. In Proceedings of the 15th CTE Congress, Bari, Italy, 4-6 November 2004.

53. Binda, L.; Papayianni, I.; Toumbakari, E.; Van Hees, R. Mechanical tests on mortars and assemblages. In Characterisation of Old Mortars with Respect to their Repair - Final Report of RILEM TC 167-COM; RILEM Publications SARL: Bagneux, France, 2004; Volume 28, pp. 57-76. [CrossRef]

54. Degryse, P.; Elsen, J.; Waelkens, M. Study of ancient mortars from Sagalassos (Turkey) in view of their conservation. Cem. Concr. Res. 2002, 32, 1457-1463. [CrossRef]

55. Lanas, J.; Pérez Bernal, J.L.; Bello, M.; Alvarez-Galindo, J.I. Mechanical properties of natural hydraulic lime-based mortars. Cem. Concr. Res. 2004, 34, 2191-2201. [CrossRef]

56. Drdácký, M.; Masin, D.; Mekonone, M.D.; Slizkova, Z. Compression tests on non-standard historic mortar specimens. In Proceedings of the 1st Historical Mortar Conference, Lisbon, Portugal, 24-26 September 2008; pp. 24-26.

57. Drougkas, A.; Roca, P.; Molins, C. Compressive strength and elasticity of pure lime mortar masonry. Mat. Struct. 2015, 49, 983-999. [CrossRef]

58. Brook, J.J.; Abu Baker, B.H. The modulus of elasticity of masonry. Mason. Int. 1998, 12, 58-63.

59. Tassios, T.P. Meccanica Delle Murature; EPC: Napoli, Italy, 1988. Available online: https://www.epc.it/contenuti/ bufarini_mecc_murature_sito.pdf (accessed on 1 April 2020).

60. Wolde-Tinsae, A.M.; Atkinson, R.H.; Hamid, A.A. State-of-the-art: Modulus of elasticity. In Proceedings of the 6th North American Masonry Conference, Philadelphia, PA, USA, 1 June 1993; The Masonry Society: Boulder, CO, USA; pp. 1209-1220.

61. Drysdale, R.G.; Hamid, A.A.; Baker, L.R. Masonry Structures: Behaviour and Design; Prentice-Hall: Englewood Cliffs, NJ, USA, 1994.

62. Brooks, J. Concrete and Masonry Movements; Butterworth-Heinemann Elsevier: Oxford, UK, 2015.

63. ICC, International Code Consortium. International Building Code; IBC: Falls Church, VA, USA, 2003.

64. Masonry Standards Joint Committee (MSJC). Building Code Requirements for Masonry Structures; ACI 530-02/ ASCE 5-02/TMS 402-02; American Concrete Institute, Structural Engineering Institute of the American Society of Civil Engineers, The Masonry Society: Detroit, MI, USA, 2002.

65. Canadian Standards Association (CSA). Design of Masonry Structures, S304.1; CSA: Mississauga, ON, Canada, 2004.

66. Zavalis, R.; Jonaitis, B.; Lourenco, P.B. Analysis of bed joint influence on masonry modulus of elasticity. In Proceedings of the 9th International Masonry Conference, Guimarães, Portugal, 7-9 July 2014. [CrossRef]

67. De Matteis, G.; Corlito, V.; Guadagnuolo, M.; Tafuro, A. Seismic vulnerability assessment and retrofitting strategies of Italian masonry churches of the Alife-Caiazzo Diocese in Caserta. Int. J. Archit. Herit. 2019. [CrossRef]

68. Guadagnuolo, M.; Aurilio, M.; Faella, G. Retrofit assessment of masonry buildings through simplified structural analysis. Frat. E Int. Strut. 2020, 14, 398-409. [CrossRef] 
69. Costigan, A.; Pavía, S.; Kinnane, O. An experimental evaluation of prediction models for the mechanical behaviour of unreinforced, lime-mortar masonry under compression. J. Build. Eng. 2015, 4, 283-294. [CrossRef]

70. Kaushik, H.B.; Rai, D.C.; Jain, S.K. Stress-strain characteristics of clay brick masonry under uniaxial compression. ASCE J. Mat. Civil. Eng. 2007, 19, 728-739. [CrossRef]

71. Marotta, A.; Liberatore, D.; Sorrentino, L. Estimation of unreinforced tuff masonry compressive strength based on mortar and unit mechanical parameters. In Proceedings of the 16th International Brick and Block Masonry Conference, Padova, Italy, 26-30 June 2016.

72. CEN, European Committee for Standardization. EN 1015-11:1999, Methods of Test for Mortar for Masonry: Determination of Flexural and Compressive Strength; CEN: Brussels, Belgium, 2006.

73. CEN, European Committee for Standardization. EN 772-1:2011, Methods of Tests for Masonry Units: Determination of Compressive Strength; CEN: Belgium, Brussels, 2011.

74. Nicotera, P.; Lucini, P. La costituzione geologica del sottosuolo di Napoli nei riguardi dei problemi. In Proceedings of the VIII Convegno di Geotecnica, Cagliari, Italy, 1967.

75. Faella, C.; Martinelli, E.; Nigro, E.; Paciello, S. Tuff masonry walls strengthened with a new kind of cfrp sheet: Experimental tests and analysis. In Proceedings of the 13th World Conference on Earthquake Engineering, Vancouver, BC, Canada, 1-6 August 2004.

76. Domède, N.; Pons, G.; Sellier, A.; Fritih, Y. Mechanical behaviour of ancient masonry. Mat. Struct. 2008, 42, 123-133. [CrossRef]

77. Page, A.W. The biaxial compressive strength of masonry. Proc. Inst. Civ. Eng. 1981, 71, 893-906. [CrossRef]

78. Vermeltfoort, A.T.; Martens, D.R.W.; Van Zijl, G.P.A.G. Brick-mortar interface effects on masonry under compression. Can. J. Civ. Eng. 2007, 34, 1475-1485. [CrossRef]

79. Chagneau, F.; Levasseur, M. Contrôle des matériaux de construction par dynamostratigraphie. Mat. Struct. 1989, 22, 231-236. [CrossRef]

80. Gucci, N.; Barsotti, R. A non-destructive technique for the determination of mortar load capacity in situ. Mat. Struct. 1995, 28, 276-283. [CrossRef]

81. RILEM TC 177-MDT. Test method recommendations of RILEM TC 177-MDT Masonry durability and on-site testing-D.1: Indirect determination of the surface strength of unweathered hydraulic cement mortar by the drill energy method. Mater. Struct. 2004, 37, 485-487. Available online: https://www.rilem.net/images/ publis/1617.pdf (accessed on 1 April 2020).

82. RILEM TC 177-MDT. Test method recommendations of RILEM TC 177-MDT Masonry durability and on-site testing-D.4: In-situ stress tests based on the flat jack. Mater. Struct. 2004, 37, 491-496. Available online: https://www.rilem.net/images/publis/1619.pdf (accessed on 1 April 2020).

83. RILEM TC 177-MDT. Test method recommendations of RILEM TC 177-MDT Masonry durability and on-site testing-D.5: In-situ stress-strain behaviour tests based on the flat jack. Mater. Struct. 2004, 37, 497-501. Available online: https://www.rilem.net/images/publis/1620.pdf (accessed on 1 April 2020).

84. Pelà, L.; Roca, P.; Benedetti, A. Mechanical characterization of historical masonry by core drilling and testing of cylindrical samples. Int. J. Archit. Herit. 2016, 10, 360-374. [CrossRef]

85. Cescatti, E.; Dalla Benetta, M.; Modena, C.; Casarin, F. Analysis and evaluations of flat jack test on a wide existing masonry buildings sample. In Proceedings of the 16th International Brick and Block Masonry Conference, Padova, Italy, 26-30 June 2016.

86. British Standards Institution. BS 5628-1: Code of Practice for the Use of Masonry. Structural Use of Unreinforced Masonry; British Standards Institution: London, UK, 2005.

87. Valluzzi, M.R.; Munari, M.; Modena, C.; Binda, L.; Cardani, G.; Saisi, A. Multilevel approach to the vulnerability analysis of historic buildings in seismic areas Part 2: Analytical interpretation of mechanisms for the vulnerability analysis and the structural improvement. Restor. Build. Monum. 2007, 13, 427-441. [CrossRef]

88. ASTM C1197-14A. Standard Test Method for In-Situ Measurement of Masonry Deformability Properties Using the Flat-Jack Method; ASTM International: West Conshohocken, PA, USA, 2014. Available online: https: //www.astm.org/Standards/C1197.htm (accessed on 1 April 2020).

89. Kingsley, G.R.; Noland, J.L. A note on obtaining in-situ load-deformation properties of unreinforced brick masonry in the united states using flatjacks, evaluation and retrofit of masonry structures. In Proceedings of the Second Joint USA-Italy Workshop on Evaluation and Retrofit of Masonry Structures, Boulder, CO, USA, August 1987; pp. 215-223. 
90. Andreini, M.; De Falco, A.; Giresini, L.; Sassu, M. Mechanical characterization of masonry walls with chaotic texture: Procedures and results of in-situ tests. Int. J. Archit. Herit. 2014, 8, 376-407. [CrossRef]

91. Almeida, C.; Guedes, J.; Arêde, A.; Costa, C.Q.; Costa, A. Physical characterization and compression tests of one leaf stone masonry walls. Constr. Build. Mater. 2012, 30, 188-197. [CrossRef]

92. Binda, L.; Tiraboschi, C. Flat-jack test as a slightly destructive technique for the diagnosis of brick and stone masonry structures. Restor. Build. Monum. 1999, 5, 449-472. [CrossRef]

93. Manning, E.C.; Ramos, L.F.; Fernandes, F. Tube-jack testing: Regular masonry wall testing. In Proceedings of the SAHC2014-9th International Conference on Structural Analysis of Historical Constructions, Mexico, Mexico, 14-17 October 2014.

94. Porco, F.; Uva, G. Alcune considerazioni sull'applicazione della tecnica dei martinetti piatti su murature caotiche. In Proceedings of the Atti della XII Conferenza Nazionale sulle Prove non Distruttive, Monitoraggio, Diagnostica Milano, 11-13 October 2007.

95. Ramos, L.F.; Manning, E.C.; Fernandes, F.; Fangueiro, R.; Azenha, M.; Cruz, J.; Sousa, C. Tube-jack testing for irregular masonry walls: Prototype development and testing. NDT $\mathcal{E}$ E Int. 2013, 58, 24-35.

96. Simões, A.; Bento, R.; Gago, A.; Lopes, M. Mechanical characterization of masonry walls with flat-jack tests. Exp. Tech. 2015, 40, 1163-1178.

97. Uranjek, M.; Bosiljkov, V.; Žarni'c, R.; Bokan-Bosiljkov, V. In situ tests and seismic assessment of a stone-masonry building. Mat. Struct. 2012, 45, 861-879. [CrossRef]

98. Alecci, M.; De Stefano, M.; Luciano, R.; Marra, A.; Stipo, G. Numerical investigation on the use of flat-jack test for detecting masonry deformability. J. Test. Eval. 2020. [CrossRef]

99. Binda, L.; Cardani, G.; Saisi, A.; Valluzzi, M.R.; Munari, M.; Modena, C. Multilevel approach to the vul-nerability analysis of historical buildings in seismic areas, Part 1: Detection of parameters for vulnerability analysis through on site and laboratory investigation. Restor. Build. Monum. 2007, 13, 413-426. [CrossRef]

100. Parivallal, S.; Kesavan, K.; Ravisankar, K.; Sundram, B.A.; Ahmed, A.K.F. Evaluation of in situ stress in masonry structures by flatjack technique. In Proceedings of the National Seminar \& Exhibition on Non-destructive Evaluation, Chennai, India, 8-10 December 2011.

101. Gregorczyk, P.; Lourenço, P.B. A review on flat-jack testing. Eng. Civil. 2000, 9, 39-50.

102. Valluzzi, M.R. Consolidamento E Recupero Delle Murature; Gruppo Editoriale: Faenza, Italy, 2003.

103. Noland, J.L.; Atkinson, R.H.; Schaller, M.P. A review of the flat-jack method for Nondestructive evaluation. In Proceedings of the Nondestructive evaluation of civil structures and Materials, Boulder, CO, USA, 15-17 October 1990.

104. Ronca, P.; Tiraboschi, C.; Binda, L. In-situ flat-jack tests matching new mechanical interpretations. In Proceedings of the 11th International Brick/Block Masonry Conference, Shanghai, China, 4-16 October 1997.

105. Saisi, A.; Gentile, C.; Cantini, L. Post-earthquake assessment of a masonry tower by on-site inspection and operational modal testing. In Proceedings of the ECCOMAS Thematic Conference- COMPDYN 2013: 4th International Conference on Computat, Kos Island, Greece, 12-14 June 2013.

106. Hendry, A.W. Structural Brickwork; The Macmillan Press: London, UK, 1981.

107. Witzany, J.; Čejka, T.; Zigler, R. The analysis of nonstress effects on historical stone bridge structures (monitoring, theoretical analysis, maintenance). In Proceedings of the the 10th East Asia Pacific Conference on Structural Engineering and Construction (EASEC-10), Bangkok, Thailand, 3-5 August 2006; Volume 6, pp. 21-26.

108. Witzany, J.; Čejka, T.; Zigler, R. Failure resistance of the historic stone bridge structure of Charles Bridge. I: Susceptibility to nonstress effects. J. Perf. Constr. Facil. 2008, 22, 71-82. [CrossRef]

109. Proske, D.; van Gelder, P. Safety of Historical Stone Arch Bridges; Springer: Berlin, Germany, 2009.

110. Vasconcelos, G.; Lourenço, P.B. Experimental characterization of stone masonry in shear and compression. Constr. Build. Mater. 2009, 23, 3337-3345. [CrossRef]

(C) 2020 by the authors. Licensee MDPI, Basel, Switzerland. This article is an open access article distributed under the terms and conditions of the Creative Commons Attribution (CC BY) license (http://creativecommons.org/licenses/by/4.0/). 